\title{
IMPLEMENTATION OF TRENDS IN HUMAN RESOURCES MANAGEMENT AS A PRECONDITION FOR BUSINESS PERFORMANCE
}

\author{
Nella Svetozarovová* \\ University of Prešov, \\ Faculty of Management and \\ Business, Prešov, Slovakia \\ nella.svetozarovova@unipo.sk
}

Tomáš Kincl

University of Economics, Faculty of Management, Jindřichův Hradec, Czech Republic

tomas.kincl@vse.cz

Jana Cocul'ová

University of Prešov, Faculty of Management and Business, Prešov, Slovakia jana.coculova@unipo.sk

\section{Anna Burdová}

University of Prešov, Faculty of Management and Business, Prešov, Slovakia anna.burdova@unipo.sk

* corresponding author

Received: November, 2021

1st Revision: December, 2021

Accepted: December, 2021

\begin{abstract}
The transforming world, globalization, dynamic technological development and the massive impact of the pandemic on economic development have forced companies to make a rapid transition from a traditional to a modern approach to managing and implementing innovations and trends. This new progressive worldview on the formation of the new generations, with attributes and values typical for the past, has contributed to the process of adapting and responding to business challenges in human resources management. This article aims to analyze statistically significant differences in implementation trends of human recourses practices, more specifically in the conditions of multinational companies operating in the European area as a precondition for business sustainability and increasing their performance potential in pandemic times. We will focus on trends in human resource management - outsourcing, onboarding, age management, knowledge management and talent management in terms of the effectiveness of their implementation in the conditions of 161 multinational companies. The reason for choosing this type of companies and testing in the multinational environment is its uniqueness related to cultural diversity, workforce, communication and sharing the knowledge and innovations.
\end{abstract}

Keywords: management, human resource, performance, trends, covid-19

JEL Classification: M53

DOI: $10.54933 / \mathrm{jmbrp}-2021-13-2-7$

Svetozarovová, N., Kincl, T., Cocul'ová, J. \& Burdová, A. (2021).

Implementation of Trends in Human Resources Management as a

Precondition for Business Performance. Journal of Management and

Business: Research and Practice, 13(2). doi: 10.54933/jmbrp-2021-13-2-7 


\section{Introduction}

The main problem in the human resource management of multinational companies is the ability to effectively transfer human resources management practices and procedures (i.e., those that have proven to be an efficient tool in the parent company) to foreign subsidiaries. Those companies that can prove this ability dispose of one of the most significant characteristics for successful multinational companies (Taylor, 1996 In: Riege, 2007).

This fact has significant practical meaning to managers of multinational companies (Minbaeva, 2005) in the field of human resources management because that transfer may also constitute some form of competitive advantage for multinational companies, and thus their other competing companies will not be able to emulate them (Flood, 2003 In: Riege, 2007). Schawbel (2014), in his predictions related to trends in the labor market, pointed out the fact that: "While most companies are still trying to focus to understand the specification and the contribution with representants of generation $\mathrm{Y}$, some of the companies are already preparing to invest heavily into generation $\mathrm{Z}$ in the form of internships or scholarship for the greatest talents "(those born in 19942010, and while the oldest one from this group are already at the universities at that time) (Mudrík et al, 2020).

Whether the practitioners or theorists, both agree that human resources are the most influential in the vast majority of the firms and make a decision about their success or failure (Cocul'ová, Svetozarovová, \& Bertová 2020). The main tasks of human resources are a determination of all the plans and goals for the companies. Without human resources, the companies will not operate in a fully and quality state (Svetozarovovová \& Sojka, 2015).

The impact of the pandemic forces companies to make an immediate transition to emergency mode, austerity measures, cost elimination and optimization of human resource management processes.

\section{From Traditional to Modem Human Resource Management - Innovation and Trends}

Dianhua (2007) states that "human resource management is an expression of diverse characteristics in different countries, different professions and different companies" and reflects the need for a responsible approach to implementing the best human resource management practices and methods. The evaluation performance methods should be included and consider any specificities related to the company's nature or the country itself (Nastišin et al., 2018). At present, the contribution of human resource management in improving a firm's performance and in the overall success of any organization (alongside other factors) is being highlighted in the literature (Schuler \& Jackson, 2005; 2007). John Storey (2007) states that it has been recognized from the outset that this term uses in two different ways. On the one hand, HRM is a general term that refers to any approach to employment management. On the other hand, HRM refers to one particular and probably the least helpful form of employment management approach. Both ways are defensible and both are currently used. Each of them uses its advantages and has its limitations.

To cope with the ever-changing and global world, an organization must use trends in its management. Kocianová (2012) states that the area of people management has developed relatively quickly in recent years, both worldwide and in our country, and thus approaches and personnel management methods have changed. Personnel management currently requires understandable organizational processes that affect organizational performance. The importance of people for an organization grows with increasing costs and investment in human capital; additionally, the importance of skills growth, motivation and flexibility of employees in organizational performance and its effectiveness to use the other sources (Svetozarovová et al., 2020). The rapidly transforming business environment means that there are currently many human resource management issues and challenges that are likely to continue in the coming years. Tom Marsden, director of professional services for Alexander Mann Solutions, said that human resources departments need to add real value to their organizations. "Even the restrictions of recession have not ended yet, the organizations are aware to take steps to sustain their workforce, by the emphasis to increase the importance of programs for training and engagement or investments into the areas that optimize costs such as integrated systems of technology or improved systems to attract the applicants. All indications point that human resources departments are preparing to maximize their resources and employees as organizations grow" (BISK, 2016). 
According to Chiavento (2001), the new philosophy is inevitable in the new millennium. The concept "Human resources management "should be replaced by new terms "Personnel management ", within the growing responsibility of middle management. People can primarily be considered human beings and not as resources for organizations. This concept means that employees at all levels should be engaged in organizations' business and yet responsible for the business outcomes. To be responsible means that all employees have and use all available information, apply their knowledge and skills, and manage their decisions to achieve desired success.

Human resources management is a very intensively discussed issue in terms of practices, business sustainability and organizational effectiveness in pandemic times. Many studies have been carried out in this regard (Caligiuri et al., 2020; Gigauri, 2020; Meri, 2020) verified the positive statistically significant relationship between trends in human resources management - practices and effectiveness in the most part. Nevertheless, this relationship remains insufficiently clarified. It seems that without presenting the benefits of investment into human resources practices, the decisions will be based on no exact explanations (Sojka et al., 2016). Even the methodology for evaluating practices values in human resources to efficiency has not yet been solved.

Even during these pandemic times, it is inevitable to do research focusing on the relationship between effective performance management and sustainability of organizations, and its importance is valued both for national and international standards. To know facts/situations in which an organization is successful and (because) its practices are systematically and adequately chosen, it unconditionally requires the evaluation of performance and competitiveness (Svetozarovová et al., 2020). Many studies prove the positive effects of realization for sustainable business in organizations (Ključnikov et al., 2019). The further it goes, the more the recognition of integrating sustainability into business is recognized in the benefits of creating unique added value and competitiveness of the company through effective human resource management. The individual benefits, such as organization reputation, improved employee's moral and competitive reinforcement influence in organizational performance (Crowther, 2012). The individual studies conducted by different authors from different geographical and time periods have confirmed the relationship between management, sustainability, and performance. The vast majority of them proved a positive correlation. Based on the statistically significant existence of correlation, it is clear that as a result of this relationship, companies implement sustainability strategies more than ever, and therefore the new impacts on an individual area of organizational performance result in increasing competitive potential of companies in the market. The impact of implementing a business sustainability strategy on the organizational performance of companies was a matter of research by Deloitte organization $(2011,2012,2013)$.

Implementation of the trends in human resources management practices as a precondition for the business sustainability and increment of their performance potential is needed even during this pandemic when the organizations must continuously react to new challenges in human resources management. The method of outsourcing has been well known and implemented for several years, but at present, a new trend that pays attention to is IT outsourcing, in which it is possible to look at some perspectives of development when the outsourcing market is becoming more professional, centralized and more widely spread. The top management task in terms of outsourcing is to identify key processes to gain a competitive advantage. These processes should be implemented by their own resources, while others can be outsourced and regularly reviewed (Dvořáček \& Tyll, 2010).

One of the other most significant trends of today is onboarding. The precondition of onboarding is the proactive approach of a new employee (Cooper-Thomas et al., 2006). From the point of view of human capital, the sooner and to a greater extent new employees can acquire specific knowledge, understand corporate culture and distinguish other unique aspects of the organization, the sooner these employees will then be able to contribute to organization success and success of the organization among its competitors (Klein et al., 2015).

The greatest assets in many organizations are the talents, knowledge and skills of employees in a continuously changing world (Lewis \& Heckman, 2006; Collings \& Mellahi, 2009). Many authors agree that talent management is the most challenging requirement for organizations nowadays (Scullion, Collings, \& Caliguiri, 2010). According to authors Mellahi \& Collings (2009), in a global context, talent management can be understood as the practice of human resources management that aims to balance various multi-directionally market power, the employee's needs and economic interests. The condition for the effective functioning of talent management in organizations is its initiatives and support from the management and its links to an organization's business strategy. The results of this strategy and practical tool for managing talented employees are then the individual talent management processes - acquirement, development and talent sustainability. Pruis (2011) 
states that talent development does not bring out the best only in organizations. The employee input largely complements organizational needs. However, information on education and development can give us insight into why investing in talent education and development is so important. The competitive advantage which leads to valuable, rare, inimitable changes in human resources can be divided into two groups: training as an integral part of human resource management and training related to talent retention

The key to success in the competitive environment of the global economy becomes the effective use of people's knowledge, skills and creativity. A response to mentioned requirements is the new discipline: knowledge management, in which all recent developmental trends have concentrated and, what's more, is systematically developing the way of intellectual capital, identification, acquirements, sustainability. It is a mutual exchange of knowledge that significantly supports the active involvement of the subject in knowledgeable society, i.e., transition to a knowledgeable organization (Čarnický \& Mesároš, 2006).

The problem of an ageing workforce and situations of ageing workers and organizations that employ those workers has come to considerable attention recently. Thus, age management is considered a new trend in human resources management. Age management is nowadays developing in terms of human active ageing, management diversity and the concept of social responsibility to a healthy organization. It focuses on the conflict against discrimination based on age and unemployment, promoting adequate human resources management and ensuring suitable working conditions (Kuperus et al., 2011; Novotný et al., 2014).

\section{Methodology}

This article aims to analyze statistically significant differences in trends implementation of human resources management practices, specifically in the condition of multinational companies as a precondition of business sustainability and increasing the potential of their performance. According to aim, the hypothesis was formulated:

H1: We assume statistically significant differences in the use of the individual trends in human resources management in terms of the performance of multinational companies.

We will focus on the trends in human resources management - outsourcing, onboarding, age management, knowledge management and talent management, in terms of their implementation level and effectiveness of practice realization during the pandemic time. For this research, the individual trends were asset into several characteristics that we would evaluate which of them within the trends is the most used. We also tested the individual characteristics among themselves, whether there are any statistical differences in use between them. We use a nonparametric statistic for the statistical measure, specifically the Friedman test between dependent variables. We aim to compare several and more dependent variables in terms of analyses of variance. The test results report the value $p$ as probability, which has to be lower than the selected level of significance, which of value is less than 0.05 . The statistical differences increase significantly with decreasing $\mathrm{p}$-value $(\mathrm{p}<0.05)$. To interpret the results, we applied the convention of indicating a level of statistical significance $p<0.05=$ low level of significance, $p<0,01=$ medium level of significance and $p<0.001=$ high level of significance.

\section{Results}

Our research results of using the practices in multinational companies were as follows. The multinational companies with a higher percentage use Outsourcing $(80.1 \% ; n=129)$ as the most common trend in human resources. After it is followed by Age management $(73.3 \% ; n=118)$, Knowledge management (68.9\%; $\mathrm{n}=111)$, Onboarding (55.3\%; $\mathrm{n}=89$ ) and Talent management $(34.2 \%$; $\mathrm{n}=55$ ). As stated earlier, we researched the existence of statistically significant differences in using individual trends in human resources management regarding their impact on effectiveness and business sustainability. The values of averages are balanced between the individual trends, as presented in the following tables. 
Table 1. Relationship trend outsourcing selected characteristics and performance Friedman's ANOVA $(\mathrm{N}=129, \mathrm{df}=6)=73.89297 \mathrm{p}=.00004$ Kendall's coefficient $=.09547 \mathrm{r}=.08840$

\begin{tabular}{lllll} 
& Average order & Sum of order & M & SD \\
\hline Recruitment & 4.348837 & 561.0000 & 101.9922 & 0.914263 \\
Training & 4.496124 & 580.0000 & 102.2016 & 0.764238 \\
Coaching & 4.244186 & 547.5000 & 101.9767 & 1.034296 \\
Accounting & 3.957364 & 510.5000 & 102.0310 & 1.217952 \\
Legal advice & 3.895349 & 502.5000 & 102.0233 & 1.201985 \\
External suppliers & 4.313953 & 556.5000 & 101.9767 & 0.785266 \\
Other & 2.744186 & 354.0000 & 101.3721 & 0.781323 \\
\hline
\end{tabular}

Source: own processing

We found out that outsourcing as a trend in human resource management is used in the case of 80.1\% ( $\mathrm{n}=129)$ in a sample of multinational companies. To assess the outsourcing trend, in terms of impact on efficiency, 7 variables were identified - the areas that companies do not carry out at their own expense, such as recruitment, training, coaching, etc. Based on the results of Friedman's ANOVA and Kendall's coefficient of agreement, a statistically significant difference between the individual characteristics in terms of impact on companies efficiency and business sustainability was confirmed in the case of trend outsourcing ( $\mathrm{p}=.00004)$, as the value of probability $\mathrm{p}$ is lower than the selected level of significance 0.05 .

Table 2. Relationship trend onboarding selected characteristics and performance

Friedman's ANOVA $(\mathrm{N}=89, \mathrm{df}=5)=17.05854 \mathrm{p}=.00439$

Kendall's coefficient $=.03833 \mathrm{r}=.02741$

\begin{tabular}{|c|c|c|c|c|}
\hline & Average order & Sum of order & $\mathbf{M}$ & SD \\
\hline $\begin{array}{l}\text { Inclusion in the team } \\
\text { and acquaintance } \\
\text { with the closest } \\
\text { colleagues }\end{array}$ & 3.578652 & 318.5000 & 102.0449 & 0.767376 \\
\hline $\begin{array}{l}\text { Integration into the } \\
\text { work process }\end{array}$ & 3.426966 & 305.0000 & 102.0112 & 0.804736 \\
\hline $\begin{array}{l}\text { The right information } \\
\text { - about the company, } \\
\text { the basic rules and } \\
\text { culture }\end{array}$ & 3.713483 & 330.5000 & 102.0899 & 1.062164 \\
\hline $\begin{array}{l}\text { The right information } \\
\text { - about the method of } \\
\text { evaluation and } \\
\text { remuneration }\end{array}$ & 3.741573 & 333.0000 & 102.0674 & 1.020224 \\
\hline $\begin{array}{l}\text { Detailed information } \\
\text { about the acquired } \\
\text { job description }\end{array}$ & 2.932584 & 261.0000 & 101.7079 & 0.800600 \\
\hline $\begin{array}{l}\text { Setting basic working } \\
\text { conditions }\end{array}$ & 3.606742 & 321.0000 & 102.1011 & 1.168186 \\
\hline
\end{tabular}

Source: own processing

The relationship between onboarding as another significant trend in human resource management and the degree of efficiency is presented in more detail in Table 2. A total of six selected characteristics of onboarding were tested, such as integration into the team and acquaintance with the closest collaborators, integration into the work process, or setting the basic working conditions. We can state that onboarding is used by more than half of multinational companies, namely $55.3 \%$ ( $\mathrm{n}=$ 89). The results of Friedman's ANOVA and Kendall's coefficient of agreement indicate the existence of statistically significant differences in the use of onboarding as one of the trends in human resource management in the conditions of multinational companies operating in Europe during the pandemic, as $\mathrm{p}=.00439$, $\mathrm{p}$ selected significance level 0.05 . 
Table 3. Relationship trend age management selected characteristics and performance

Friedman's ANOVA $(\mathrm{N}=118, \mathrm{df}=5)=60.71568 \mathrm{p}=.00001$

Kendall's coefficient $=.10291 \mathrm{r}=.09524$

\begin{tabular}{|c|c|c|c|c|}
\hline & Average order & Sum of order & M & SD \\
\hline $\begin{array}{l}\text { A fair approach to } \\
\text { aging and better } \\
\text { information on aging }\end{array}$ & 3.855932 & 455.0000 & 102.6441 & 1.250815 \\
\hline $\begin{array}{l}\text { Supporting work } \\
\text { ability and } \\
\text { performance }\end{array}$ & 4.330508 & 511.0000 & 102.9746 & 1.229703 \\
\hline $\begin{array}{l}\text { Lifelong learning, } \\
\text { including non - } \\
\text { formal education }\end{array}$ & 3.364407 & 397.0000 & 102.2542 & 1.206722 \\
\hline $\begin{array}{l}\text { Age-friendly working } \\
\text { conditions }\end{array}$ & 3.449153 & 407.0000 & 102.2712 & 1.251741 \\
\hline $\begin{array}{l}\text { Management of age } \\
\text { issues included in } \\
\text { human resources } \\
\text { policy }\end{array}$ & 3.055085 & 360.5000 & 102.1441 & 1.006606 \\
\hline $\begin{array}{l}\text { Safe and dignified } \\
\text { retirement }\end{array}$ & 2.944915 & $347 \cdot 5000$ & 102.0000 & 0.886750 \\
\hline
\end{tabular}

Source: own processing

The equitable approach to ageing and better information on ageing, supporting working ability and performance, lifelong learning including informal training, age-friendly working conditions, management of age issues in the human resources policy, safe and dignified transition to retirement: are the all selected characteristics that were tested in the relationship to the effectiveness in terms of age management practices. A total of six activities were again selected and tested, and they should be provided in the company in terms of age management, which based on results from questionnaire survey used in a total of $73.3 \%(\mathrm{n}=118)$ of selected companies In the case of testing above relationship, we can determine that $\mathrm{p}$ has a value of .oooo1, i. statistically significant difference between the individual characteristics determining trend management in terms of the impact on the efficiency of companies and the sustainability of the business in times of pandemic.

Table 4. Relationship trend knowledge management selected characteristics and performance

Friedman's ANOVA $(\mathrm{N}=111, \mathrm{df}=5)=9.319265 \mathrm{p}=.09699$

Kendall's coefficient $=.01679 \mathrm{r}=.00785$

\begin{tabular}{lllll} 
& Average order & Sum of order & M & SD \\
\hline $\begin{array}{l}\text { Knowledge sharing - } \\
\text { technological } \\
\text { infrastructure }\end{array}$ & 3.567568 & 396.0000 & 101.9550 & 0.975960 \\
$\begin{array}{l}\text { Connecting people - } \\
\text { selling knowledge, } \\
\text { communication }\end{array}$ & 3.202703 & 355.5000 & 101.7838 & 1.003679 \\
$\begin{array}{l}\text { Established processes } \\
\text { to simplify knowledge } \\
\text { sharing }\end{array}$ & 3.378378 & 375.0000 & 101.9459 & 0.980147 \\
$\begin{array}{l}\text { Training of educated } \\
\text { employees }\end{array}$ & 3.518018 & 390.5000 & 101.8919 & 0.918015 \\
$\begin{array}{l}\text { Support of mutual } \\
\text { education from top } \\
\text { management }\end{array}$ & 3.837838 & 426.0000 & 102.3964 & 1.515251 \\
$\begin{array}{l}\text { Established employee } \\
\text { knowledge } \\
\text { management system }\end{array}$ & 3.495495 & 388.0000 & 101.8919 & 0.897991 \\
\hline
\end{tabular}

Source: own processing 
The test results of the related knowledge management as a trend in human resources management and the efficiency level are presented in table 4 in more detail. We can mention the selected individual characteristics of knowledge management: sharing the knowledge, connecting people - passing on knowledge, support of mutual training from top management, training of educated employees, and others. Knowledge management is used by a total of $68.9 \%(n=111)$ of multinational companies operating in the EU area. The results of Friedman's ANOVA and Kendall's coefficient of agreement indicate the existence of statistically significant differences in the use of onboarding as one of the trends in human resource management in the conditions of multinational companies operating in Europe during the pandemic, as p = .09699 is higher than 0.005, and therefore statistically significant difference has not been confirmed in this case.

Table 5. Relationship trend talent management selected characteristics and performance Friedman's ANOVA $(\mathrm{N}=55, \mathrm{df}=6)=11.25361 \mathrm{p}=.12794$ Kendall's coefficient $=.02923 \mathrm{r}=.01125$

\begin{tabular}{|c|c|c|c|c|}
\hline & Average order & Sum of order & $\mathbf{M}$ & SD \\
\hline $\begin{array}{l}\text { When recruiting } \\
\text { employees, their } \\
\text { talent is taken into } \\
\text { account }\end{array}$ & 4.072727 & 224.0000 & 1.981818 & 0.971652 \\
\hline $\begin{array}{l}\text { When motivating } \\
\text { employees, their } \\
\text { talent is taken into } \\
\text { account }\end{array}$ & 3.972727 & 218.5000 & 1.945455 & 0.869614 \\
\hline $\begin{array}{l}\text { When retaining } \\
\text { employees, their } \\
\text { talent is taken into } \\
\text { account }\end{array}$ & 4.690909 & 258.0000 & 2.127273 & 0.794764 \\
\hline $\begin{array}{l}\text { When evaluating } \\
\text { employees, their } \\
\text { talent is taken into } \\
\text { account }\end{array}$ & 4.445455 & 244.5000 & 2.090909 & 1.110101 \\
\hline $\begin{array}{l}\text { The organization } \\
\text { supports the talent of } \\
\text { individuals }\end{array}$ & 4.690909 & 258.0000 & 2.200000 & 0.910840 \\
\hline $\begin{array}{l}\text { The organization } \\
\text { perceives the talent of } \\
\text { employees as a } \\
\text { competitive } \\
\text { advantage }\end{array}$ & $4 \cdot 754545$ & 261,5000 & 2.200000 & 0969918 \\
\hline $\begin{array}{l}\text { Talent is a tool for } \\
\text { managing the careers } \\
\text { of individuals }\end{array}$ & $4 \cdot 754545$ & 261,5000 & 2.163636 & 1.032143 \\
\hline
\end{tabular}

Source: own processing

The relation of talent management and its selected characteristics, regarding the efficiency point of view based on the results of Friedman's ANOVA and Kendall's coefficient of the agreement, were not confirmed (the value $\mathrm{p}=.12794$ ). A total of seven selected characteristics of talent management were tested. Based on the results, we can state that the selected researched companies use talent management the least, precisely $34.2 \%(n=55)$.

\section{Discussion}

Human resources management can be comprehended as a significant and integral part of the company. After all, the fulfillment of the organization's goals depends on human capital. The new innovative trends in human resources management, as many other trends, are taking part in the modern globalized world (Schuler \& Jackson, 2005; 2007). For the needs of our research we have chosen five trends or modern management tools that are currently the most recognized and implemented in organizations. The majority of respondents consider using the new human resources 
management trends as remarkably part of working with people. From the questionnaire results, it is clear that the most used trends are outsourcing and age management. As part of outsourcing, the most often used range of trends in multinational companies are the recruitment of employees, employees training and coaching of managers. Therefore we can state that most companies implement their project through outsourcing and to be informed about IT outsourcing as the current trend is highly demanding, but no studies can prove that IT outsourcing is the best management method (Xi et al., 2013). The reasons for adopting Age Management don't stop there. By improving their policies, companies can benefit from their worker's age diversity by having a better adjustment to various client groups (broken down by age, affluence, etc.) (Liwiński \& Sztanderska, 2010 In: Fabisiak \& Prokurat, 2012).

According to results, talent management is used the least, especially only $34.2 \%$ of respondents confirmed using the mentioned trends actively. However, when the multinational company already uses this trend, it is principally satisfied with it and evaluates it as very efficient in its impact on the employees. Within talent management is the most often used, when motivating employees and retaining employees and their talent is taken into account in both characteristics. Schraeder (2009) states that sufficient time needs to be devoted to the development and training of employees to integrate them into the organization's strategy. However, the demand for alternative methods of development and education is coming to the fore.

Knowledge management, as the concept is not known for many people, in any event of this, its practices are very often used in multinational companies. The procedures of connecting people passing on knowledge, communication - seems to be the most effective within the given trend. Approximately half of the respondents indicated that the onboarding trend is used actively within their company, but they did not evaluate it effectively. As we look at the results, we can see that the practice as the right information - about the company, basic rules and culture within onboarding is not widely used, and the respondents evaluate it negatively. According to Singh and Sharma, knowledge management and organizational learning have a positive relationship and by extension, with employee's performance (Singh \& Sharma, 2011 In: Ho 2018). In order to improve the employee's performance, knowledge management systems must be enhanced and organizations must have to adopt different policies to enhance their learning capabilities.

As the difference between the identified set of human resource management trends, in terms of impact on efficiency and sustainability of the business within multinational companies, was not confirmed in all five cases. Only in three named (onboarding, outsourcing and age management), we cannot accept the hypothesis and for this reason, reject it. Looking at the overall results of the analysis, we can say that most multinational companies use new trends and consider them to be effective in terms of impact on employees. We believe in improvements, and every company can use recent trends much more effectively because innovations in human resource management lead the company to better competitiveness.

\section{Conclusion}

In the early beginning of the 2oth century, companies began to realize the need for human resource management. They understood that just people as a resource are a competitive advantage for their company. Over time, various approaches, processes and functions of human resource management developed. Different models of human resources management have been created in the company, in which the management influence on the performance of employees was pointed out. The new type of coronavirus has affected the whole world and caused a global pandemic, but above all, it has influenced the current unstable time in which many trends and challenges still exist. The organizations, both in the domestic or multinational working market environment, will not respond promptly and practically enough, which may cause fatal consequences. Therefore, it is necessary to consider which trends are inevitable to use currently because some of them are unnecessary in every organization. On the other hand, innovative trends have to be supported and improved.

The challenges companies are currently facing should be resisted to survive in the global market. The global integration trend points out the standard recruitment, management and development of human resources - talents, to secure their competitive advantages. The organization should accept the best global and local approaches to human resources management. Every organization should make more effort to use modern managerial methods and tools, as its goal is to sustain in the market. It should follow the latest trends in leadership, decision making, organizing and controlling. Also, try to motivate employees and gain qualified, talented and highly performed employees who are willing to respect trends and challenges in the business environment, even during pandemic times. 


\section{Acknowledgment}

This research was supported by the grant project 1/0237/19 - VEGA "Research of the impact of human resource management practices on organizational commitment and retention of talented and high-performing employees. " 


\section{References}

BISK, (2020). Human Resource Management Challenges. Retrieved from: https://www.villanovau.com/resources/hr/human-resource-managementchallenges/\#.WkngzffiaUm

BSI GROUP, (2014). How sustainability standards can drive business performance. Retrieved from: https://www.bsigroup.com/globalassets/LocalFiles/enGB/standards/BSI-sustainabilityreport-how-sustainability-standards-can-drive-business-performance-UK-EN.pdf

Caligiuri, P., De Cieri, H., Minbaeva, D., Verbeke, A., Zimmermann, A. (2020). International HRM Insights for Navigating the COVID-19 Pandemic: Implications for Future Research and Practice. Journal of International Business Studies, 51(5), 697-713.

Čarnický, Š., Mesároš, P. (2006). The need to implement knowledge management in Slovak companies. Journal of Economics, 54(4), 386-402.

Cocul'ová, J., Svetozarovová, N., Bertová, D. (2020). Analysis of Factors Determining the Implementation of Talent Management, Marketing and Management of Innovations, 3, 249256.

Collings, D.G., Mellahi, K. (2009). Strategic Talent Management: A review and research agenda. Human Resource Management Review, 19 (4), 304-313.

Cooper-Thomas, H.D., Anderson, N. (2006). Organizational socialization: A new theoretical model and recommendations for future research and HRM practices in organizations. Journal of Managerial Psychology, 21(5), 492-516.

Crowther, D., Aras, G. (2009). The Durable Corporation: Strategies for Sustainable Development. Farnham: Gower.

Delloite (2014). CFOs and Sustainability: Shaping their Roles in an evolving environment. Retrieved from: $\quad$ https://www2.deloitte.com/content/dam/Deloitte/global/Documents/Risk/dttl-riskDeloitte-CFOs_and_Sustainability-2014.pdf

Dianhua, W. (2007). The Mode of Human Resource Management in Developed Countries and it 's Enlightenment for Enterprises of China. Management Science and Engineering, 1(1), 66-74.

Dvořáček, J., Tyll, L. (2010). Outsourcing and offshoring of business activities. Praha: C. H. Beck.

Fabisiak, J., Prokurat, S. (2012). Age Management as a Tool for the Demographic Decline in the 21st Century: An Overview of its Characteristics. Journal of Entrepreneurship, Management and Innovation, 8(4), 83-96.

Gigauri, I. (2020). Influence of Covid-19 Crisis on Human Resource Management and Companiesâ€ $€^{\mathrm{TM}}$ Response: The Expert Study. International Journal of Management Science and Business Administration, 6(6), 15-24.

Ho, O. (2018). Knowledge Management. Journal of Business \& Financial Affairs, o7(02), 1-5.

Chiavenato, I. (2001). Advances and Challenges in Human Resource Management in the New Millenium. Public Personnel Management, 30(1), 17-26.

Klein, H., Polin, B., Leigh Sutton, K. (2015). Specific Onboarding Practices for the Socialization of New Employees. International Journal of Selection and Assessment, 23(3), 263-283.

Ključnikov, A., Mura, L., \& Sklenár, D. (2019). Information security management in SMEs: factors of success. Entrepreneurship and Sustainability Issues, 6(4), 2081.

Kocianová, R. (2012). Personnel management: starting points and development. Praha: Grada.

Kuperus, H., Stoykova, P., Rode, A. (2011). Baseline Study. Retrieved from: http://esfage.eu/sites/esfage/files/attachments/Baseline_Study_August2011.pdf

Lewis, R. E., Heckman, R. J. (2006). Talent management: A critical review, Human Resource Management Review, 16(2), 139-154.

Liu, W. (2004). The cross-national transfer of HRM practices in MNCs: An integrative research model, International Journal of Manpower, 25(6), 500-517.

Meri, M. (2020). New Trends in HRM \& Knowledge Management in the Health Sector beyond COVID19 - A Practical Model, Business Excellence and Management, S.I.(1), 5-21.

Minbaeva, D. (2005). HRM practices and MNC knowledge transfer, Personnel Review, 34(1), 125144.

Mudrík, M., Rigelský, M., Gavurová, B., Bačík, R., Fedorko, R. (2020). Comparison of influence of selected viral advertising attributes on shopping behavior of Millennials - empirical study, Innovative marketing, 16(3), 14-25.

Nastišin, L., Bačík, R., Fedorko, R., Gavurová, B. (2018). The customer's brand experience in the light of selected performance indicators in the social media environment, Journal of competitiveness, $10(2), 72-84$. 
Novotný, P. et al. (2014). Age management: jak rozumět stárnutí a jak na něj reagovat. Možnosti uplatnění age managementu v České republice. Plzeň: Grafia.

Pruis, E. (2011). The five key principles for talent development. Industrial and Commercial Training, 43(4), 206-216.

Riege, A. (2007). Actions to overcome knowledge transfer barriers in MNCs, Journal of Knowledge Management, 11(1), 48-67.

Scullion, H., Collings, D. G., P. Caligiuri. (2010). Global talent management, Journal of World Business, 45(2), 105-108.

Schawbel, D. (2014). The Top 10 Workplace Trends For 2015. Retrieved from:

https://www.forbes.com/sites/danschawbel/2014/10/29/the-top-10-workplace-trends-for 2015/?linkId=10258293\&utm_campaign=Forbes\&utm_channel=Entrepreneurs\&utm_medium $=$ social\&utm_source $=$ LINKEDIN_COMPANY\&sh $=44$ dae $51446 a 3$

Schraeder, M. (2009). Leveraging potential benefits of augmentation in employee training. Industrial and Commercial Training, 41(3), 133-138.

Schuler, R., Jackson, S. (2005). Understanding human resource management in the context of organizations and their environments, Annual review of psychology, 46(1), 237-264.

Schuler S, Jackson S.E. (2007). Strategic human resource management. London: Blackwell Publishers.

Sojka, L. et al. (2016). Praktiky riadenia l’udských zdrojov z hladiska hodnotenia ich vplyvu na výstupy organizácie. Prešov: Bookman.

Storey, J. (2007). What is human resource management?' In Storey, J. (ed) Human Resource Management: A Critical Text. London, Thomson Learning.

Svetozarovová, N., Sojka, L. (2016). An analytical view of performance evaluation in telecommunication sector ", European Journal of Science and Theology, 12(5), 255-263.

$\mathrm{Xi}, \mathrm{X}$., Xu, Y., Todo, H. (2013). The Present Situation of IT Outsourcing and Countermeasure, Journal of Software Engineering and Applications, 6(8), 426-430. 